\title{
Honour Killings and Law in India
}

\author{
Puneet Kaur Grewal \\ Senior Research Fellow Department cum Centre for Women's Studies and Development, Panjab University \\ Chandigarh, India
}

\begin{abstract}
The paper aims at highlighting the legal provisions to tackle with the crime of honour killing. The introductory part gives a glimpse of what is honour killing and which acts are considered dishonourable by the family or community. Certain acts and behaviour of individuals could become reasons for him or her to be killed by his or her own family especially male family members or the community. The next part illustrates various legal provisions in the Indian Constitution which can be used to put to stop these honour killings in the country. These laws can be used as a tool to put behind bars the khap panchayat members who give orders of killing individuals for the sake of so called honour. The next part explains the international provisions related to honour crimes to which India is signatory. The paper questions as to why despite all these provisions killings are rampant in the present times.
\end{abstract}

Keywords: Crime, Honour killings, International provisions, Law, Rights

\section{Introduction}

Honour killing is the "unlawful killing of a woman for her actual or perceived morally or mentally unclean and impure behaviour" (Hassan 1995). Honour killings are murders by families on family members who are said to have brought shame on the honour and name of family (Sheri \& Bob Stritof 2005). These are acts in which "a male member of the family kills a female relative for tarnishing the family image" (Free Dictionary by Farlex 2007). The term is also defined as the purposeful pre-planned murder, generally of a woman, by or at the command of members of her family stimulated by a perception that she has brought shame on the family (Oxford Dictionary of Law Enforcement 2007).

"Honour killings can also be described as extra-judicial punishment of a female relative for assumed sexual and marriage offences. These offences, which are considered as a misdeed or insult, include sexual faithlessness, marrying without the will of parents or having a relationship that the family considers to be inappropriate and rebelling against the tribal and social matrimonial customs. These acts of killing women are justified on the basis that the offence has brought dishonour and shame to family or tribe" (Amnesty International 1999). Another report says that "the regime of honour is unforgiving: women on whom suspicion has fallen are not given an opportunity to defend themselves, and family members have no socially acceptable alternative but to remove the stain on their honour by attacking the woman" (Amnesty International 2001).

Honour killings elucidates that the custom is not related to a feudal societal arrangement, "There are also perpetrators who are well educated university graduates. Of all those surveyed, 60 percent are either high school or university graduate or at the very least literate" as per a study by Dicle University (Gezer 2001).

\section{Constitutional Provisions:}

The Constitution of India has ample provisions allowing an individual to exercise his/her choice independent of caste, religion or gender and protection from honour related crimes including honour killings. Following are those Constitutional provisions that substantiate this:

Honour Killings are cases of homicide and murder which are grave crimes under the Indian Penal Code (IPC). Section 299 and 301 of the IPC, deals with culpable homicide not amounting to murder while Section 300, deals with murder. Honour killing amounts to homicide and murder because the acts are done with the intention of murdering the victims as they have purportedly brought dishonour upon the family. The perpetrators can be punished as per Section 302 of the IPC. The khap panchayats or family members can also be booked under Section 302 of IPC for instigating suicide those who transgress the so called norms of the community.

Such killings also violates Articles 14, 15 (1) \& (3), 17, 18, 19 and 21 of the Constitution of India.

Article 14 of the Indian Constitution guarantees to every person the right to equality before the law or the equal protection of the laws. Every person, whatever be his or her status or situation is subject to the jurisdiction of the ordinary courts. This right to equality is thus documented as one of the fundamental features of the Indian Constitution. Honour Killings are thus hideously against this very Constitutional Right provided for the protection of Indian citizens. Honour killings are mainly directed towards women and thus give rise to gender violence. 
Honour killings involve the murder of a particular person especially a woman and thus come under the ambit of Section 299 and Section 300 of the Indian Penal Code. It is also violation of Article 19 and Article 21 of the Constitution. Such brutal murders, under the garb of saving the honour of the family, are clearly against the Constitutional provisions enshrined in Article 21. Khap panchayats violate a person's fundamental right to life as they kill or instigate murder, in the name of honour. Every person has a right to live. The capital punishment is possible only when granted by law.

In cases where the khap panchayats have compellingly separated married couples who are of eligible age to get married, these have violated the provisions under the Indian Constitution.

The Indian Majority Act, Section-3, 1857 states that every person domiciled in India shall attain the age of majority on completion of 18 years and not before. Unless a particular personal law specifies otherwise, every person domiciled in India is deemed to have attained majority upon completion of 18 years of age. However, in the case of a minor for whose person or property, or both, a guardian has been appointed or declared by any court of justice before the age of 18 years, and in case of every minor the superintendence of whose property has been alleged by the Court of Wards, age of majority will be 21 years and not 18 .

The Act is relevant in cases where the khap panchayats have forcefully separated married couples who are of eligible age to get married. It is a violation of the provisions under this Act. The main reason behind the enactment of the Special Marriage Act, 1954 was to provide a special form of marriage for the people of India and all Indians residing in foreign countries, irrespective of the religion or faith followed by either party, to perform the intended marriage. Scheduled Castes and Scheduled Tribes (Prevention of Atrocities) Act, 1989 was enacted by the Parliament of India, in order to avert atrocities against Scheduled Castes and Scheduled Tribes. The intention of the Act was to help the social inclusion of Dalits into Indian society. It defines acts such as forcing an SC/ST to eat or drink any inedible or obnoxious substance, removing clothes, parading naked or with painted face or body, assaulting, dishonouring and outraging the modesty of an SC/ST woman, sexual exploitation of an SC/ST woman, forcing an SC/ST to leave his or her house or village as punishable.

The Act is linked to honour killings because numerous incidents of honour killing are in relation to caste and religion. The Protection of Human Rights (Amendment) Act, 2006 makes the provision for protection of individual rights of human beings and the constitution of a National Human Rights Commission, State Human Rights Commission and Human Rights Courts for better protection of human rights of individuals.

The Protection of Women from Domestic Violence Act, 2005 provides for more effective protection of the rights of women guaranteed under the Constitution who are victims of violence of any kind occurring within the family and for matters connected therewith or incidental thereto. For the purposes of this Act, any act, omission or commission or conduct of the respondent shall constitute domestic violence in case it -

(a) Harms or injures or endangers the health, safety, life, limb or well-being, whether mental or physical, of the aggrieved person or tends to do so and includes causing physical abuse, sexual abuse, verbal and emotional abuse and economic abuse; or

(b) harasses, harms, injures or endangers the aggrieved person with a view to coerce her or any other person related to her to meet any unlawful demand for any dowry or other property or valuable security; or

(c) has the effect of threatening the aggrieved person or any person related to her by any conduct mentioned in clause (a) or clause (b); or (d) otherwise injures or causes harm, whether physical or mental, to the aggrieved person.

The Indian Evidence Act, 1872 makes provision to punish those who conceal facts, either before or at the time of, or after the alleged crime. Article 13 of the Act: Facts relevant when right or custom is in question Where the question is as to existence of any right or custom, the following facts are relevant:

(a) Any transaction by which the right or custom in question was created, claimed modified, recognized, asserted or denied, or which was inconsistent with its existence;

(b) Particular instances in which the right or custom was claimed, recognized, or exercised, or in which its exercise was disputed, asserted, or departed from. The Act is relevant to bring to justice those who become victim because of the verdicts issued by the khap panchayats.

\section{International Provisions:}

India is a signatory to the United Nations Convention on the Elimination of all forms of Discrimination against Women (CEDAW 1979) and has also ratified the convention. The provisions of CEDAW can be used to argue that the tradition and practice of punishing individuals for ill informed ideas of dishonouring the family, is essentially institutionalised discrimination against individuals and creates a legally binding obligation for India, as a State party to the convention, to take all measures to end all forms of the practice of honour killing and ensure that all discrimination against women in matters relating to marriage and family relations are eliminated, providing them with the equal right to enter into marriage and to freely choose a spouse and to enter into marriage with their free and full consent as enumerated in Article 16 of the Indian Constitution. This means 
ensuring that informal decision making bodies functioning on customary laws, such as khap panchayats, are refrained from enforcing their dictates, and intrusive with the right of individuals to choose their spouse.

Noting that the Universal Declaration of Human Rights, (UDHR 1948) affirms the principle of the inadmissibility of discrimination and inequity and proclaims that all individuals are born free and equal in dignity and rights and freedom set fourth therein, devoid of distinction of any kind including distinction based on sex. Recalling that prejudice and discrimination against women violates the principle of equality of rights and respect of human dignity, is an obstacle to the participation of women in the political, social economic and cultural life and hampers the growth and prosperity of society and the family. All crimes of honour, including honour killing, are gross violations of the rights enumerated in the declaration.

Article 1 and 2 of the declaration state that "all human beings are born free and equal in dignity and rights," and that "everyone is entitled to all the rights and freedoms set forth in" the declaration irrespective of "sex". Therefore as enumerated in the declaration's Articles 3 and 5, women are entitled to enjoy the "right to life, liberty and security of person" and also the "right to be free from torture or cruel, inhuman and or degrading treatment". Crimes of honour violate Article 3 and 5 when the purpose of the perpetrator is to inflict severe mental and physical pain on the women.

Under Article 12 of the International Convention on Economic, Social and Cultural Rights (ICESCR 1976) State parties have to take all steps to ensure the "right of everyone to the enjoyment of the highest attainable standard of physical and mental health", is ensured. Crimes of honour that involve sexual violence and mental violence or physical or mental torture obstruct the right of women to enjoy the highest attainable standard of health. India, as a State party, is therefore legally obligated to ensure that individuals and victims of crimes of honour are able to avail this right.

While not legally binding on the State, the human rights standards enumerated in paragraph 232 of the Beijing Platform for Action (BPFA 1995) recognises that the "human rights of women include their right to have control over and decide freely and responsibly on matters relating to their sexuality, including sexual and reproductive health, free of coercion, discrimination and violence". The Beijing Platform for Action on Women's Human Rights calls upon States to "take urgent action to combat and eliminate violence against women, which is a human rights violation resulting from harmful traditional or customary practices, cultural prejudices and extremism".

Crimes of honour may involve the violation or abuse of a number of human rights, which include the right to life, liberty and security of the person; the prohibition on torture or other cruel, inhuman, or humiliating treatment or punishment; the ban on slavery; the right to freedom from gender-based discrimination; the right to privacy; the right to marry; the right to be free from sexual abuse and exploitation; the obligation to amend customs that discriminate against women; and the right to an effective remedy. All these mentioned above violate the Human Rights Act (1998). Honour Killings are a clear violation of human rights and States necessarily need to protect individuals from such violations.

Two major UN documents call for the 'elimination' of honour killing. The concept of elimination appears in the 'Declaration on the Elimination of Violence against Women' (1993) and in 'Working towards the Elimination of Crimes against Women Committed in the Name of Honour' (2003). But the eradication of any such phenomenon like honour killing requires a serious intervention in the status quo. Equal gender relations have not yet been achieved and violence still exists in the name of honour. The whole system in itself is patriarchal and insensitive. In the words of the UN Declaration on the Elimination of Violence against Women: "Violence against women is a manifestation of historically unequal power relations between men and women, which have led to discrimination over and discrimination against women by men and to the prevention of the full advancement of women, and that violence against women is one of the crucial social mechanisms by which women are forced into a subordinate position compared with men."

However constitutional law and international provisions fail to tackle with this menace. It also fails to give justification as to why such a crime is rampant even in the contemporary times when there are abundant provisions for the protection of individuals. It is strange that even after the provisions of CEDAW and various human rights provisions to eliminate violence against women; individuals continue to be the victims of murders in the name of honour.

\section{References}

[1] Amnesty International (1999). "Pakistan: Honour Killings of Girls and Women” viewed on 9 June 2011 (http://www.amnesty.org/en/library).

[2] Amnesty International (2001). "Broken Bodies, Shattered Minds: Torture and ill Treatment of Women", 6 March 2001, viewed on 9 June 2011 (http://www.amnesty.org/en/library/info/ACT40/001/2001).

[3] "CEDAW" (1979) Part 4, Article16, viewed on 9 June 2011 (http://sim.law.uu.nl/SIM/Library/HRinstruments.nsf/ec7e20097a57a8f2c1256900004b35db/7a2bc4a2abc904b3c125 663a0036afc7?OpenDocument). 
[4] "Declaration on the Elimination of Violence against Women" UN Document Series Symbol: ST/H/, UN Issuing Body: Secretariat Centre for Human Rights, Proclaimed by the General Assembly Resolution 48/104 of 20 December 1993, viewed on 9 June 2011 (http://www.un.org/documents/ga/res/48/a48r104.htm).

[5] Farlex (2007). "Honour Killings", The Free Dictionary, viewed on 9 June 2011 (http://www.thefreedictionary.com/honor+killing).

[6] Gezer, Murat (2001). "Honour Killing Perpetrators Welcomed by Society", Today’s Zaman 12 July 2008, Viewed on 9 June 2011 (http://www.todayszaman.com/tzweb/detaylar.do?load=detay\&link=147349\&bolum=101).

[7] Hassan, Yasmeen (1995). Heaven Becomes Hell: A Study of Domestic Violence in Pakistan (Lahore, Shirkat Gah).

[8] "Honour Killing" (2007). The Oxford Dictionary of Law Enforcement (Oxford, Oxford University Press) viewed on 17 July 2011 (http://www.answers.com/topic/honor-killing-1).

[9] "Human Rights Act 1998", Wikipedia: The Free Encylopedia, viewed on 17 July 2011. (http://en.wikipedia.org/wiki/Human_Rights_Act_1998).

[10] "Indian Majority Act", Wikipedia: The Free Encyclopaedia, Modified on 25 September 2010, viewed on 9 June 2011 (http://en.wikipedia.org/wiki/Indian_Majority_Act).

[11] "Scheduled Castes and Schedule Tribes (Prevention of Atrocities) Act, 1989" Act No 33 of 1989, 11 September, 1989, viewed on 9 June 2011 (http://indianchristians.in/news/images/resources/pdf/sc_and_st_prevention_of_atrocities_act_1989.pdf).

[12] Sheri \& Bon Stritof (2005). "Honour killings" viewed on 9 June 2011 (http://marriage.about.com/od/arrangedmarriages/g/honourkilling.htm).

[13] "Special Marriage Act, 1954" Wikipedia: The Free Encyclopaedia, modified on 19 March 2011, viewed on 9 June 2011 (http://en.wikipedia.org/wiki/Special_Marriage_Act, 1954). 